J. Product. \& Dev., 19(3):253 - 262 (2014)

\title{
PROTECTION OF Bombyx mori L. LARVAE AGAINST CERTAIN DISEASES USING SOME CHEMICAL DISINFECTANTS
}

\author{
A.A. Zannoon and E.M. El- Yamani \\ Plant Protection Research Institute, A.R.C., Dokki, Egypt.
}

\begin{abstract}
This study was conducted to evaluate the use of flom fort, potassium sulphonate and dettol compounds as disenfectants and their impacts on the biological characteristics and production of silk in silkworm Bombyx mori L artificially infected with bacteria that causes filahari disease.

Treatments achieved that potassium sulphonate $10.1 \%$ and $0.05 \%)$ resulted lower mortality rate, the highest percentage of adult emergency, fertility of the female and hatching percentage, and also increased the resulting cocoon weight, silk content ratio, the filament length per cocoon, weight and size of the reeled filament. flom fort $(0.1$ and $0.05 \%)$ increased adult emergence percentage, ,female fecundity, silk cocoon ratio and the length of reeled filament. while treatment of mulberry leaves with dettol $(0.1 \%)$ increased the cocoon shell weight.
\end{abstract}

Key words: Bombyx mori 1., Larvae, some chemical disinfectants.

\section{INTRODUCTION}

The mulberry silkworm diseases are very serious problem that face silkworm rearing as they cause quantitative and qualitative reduction of natural silk crop production.

Therefore, the produced cocoons by survivors have the depleted economic characters. Diseases control can only be affected by prophylactic use of certain disinfectants or antibiotics (Radha et al., 1981; Serbanescu and Pau 1989; EL-Zohairy, M.; Govindan et al., 1990; Saha et a1., 1995 ; Sanakal et al., 1996; Dechu et al. 1997; Bali et al., 2008; and Saad et al., 2012).

Owing to the economic importance of silkworm, Bombyx mori L. as the main source of natural silk the present work was under taken to investigate three chemical compounds as disinfectants on some biological aspects and silk production of the insect. 


\section{MARERIALS AND METHODS}

This work was carried out during the spring season of 2012 in laboratory of Sericulture Research Department, Sharkiya Province, Plant Protection Research Institute, Agriculture Research Center.

\section{Materials:}

1-The mulberry silkworm, Bombyx mori L.(Giza -K hybrid), obtained from the Sericulture Research Department of Plant Protection Research Institute, Agricultural Research Center, Ministry of Agriculture Giza, Egypt.

2- Mulberry leaves, Morus alba var. Balady (native).

3- Three compounds namely; flume forte (antibiotic: fluoroquinolone group), potassium sulfonate and dettol. Each was used with three concentrations ; $\quad(0.1,0.05$ and $0.025 \%)$.

4- Triton X 100 was used as emulsifier agent.

\section{Methods:}

\section{Silkworm rearing technique}

Eggs of the silkworm Bombyx mori L. (Giza $-\mathrm{K}$ hybrid) were rearing procedures were achieved under laboratory conditions of $26 \pm 2{ }^{\circ} \mathrm{c}$ and $70 \pm$ $5 \%$ RH according to technique of Krishnaswami (1978).Chicken egg cartons plates were used as montages for cocoon spinning (Zannoon and Omara 1994). The cocoons were harvested seven days after mounting. Half number of the resulted cocoons was used for the biological studies and after emergence, each couple of moths was impaired in paper sacule for copulation and oviposition. The other half of cocoons were dried in an oven to study the technological characters. The three compounds namely; flume forte, potassium sulfonate and dettol were added to mulberry leaves as disinfectants against the flacherie disease.

\section{Isolation of bacteria:}

Bacterial pathogens were collected from diseased black thorax septicemia infected larvae, the diseased larvae were crushed by using mortar and pestle and the solution was filtered. The filtrate was centrifuged at 4500 rpm for 10 minutes. The supernatant was discarded and the pellet was used for bacterial culture after resuspending in distilled water (Aneja, 2003).

\section{Infecting of silkworm larvae with bacteria:}

Newly molted $4^{\text {th }}$ instar larvae were divided into two groups; the first was left without infection (control group). The second group was fed on infected mulberry leaves of $20 \mathrm{ml} / 200 \mathrm{~g}$ leaves /100 larvae. The infected group were divided into two subgroups, the first subgroup treated with the 
investigated disinfectants and the second subgroup with distilled water. For the diseased and treated groups, the infected leaves were provided to larvae at the first feed on first day and thereafter the larvae were fed with normal leaves. Every treatment and control was included 3 replicates of 100 larvae for each treatment.

\section{Treatment by disinfectants:}

Using a small atomizer, clean mulberry leaves were sprayed with different concentrations $(0.1,0.05$ and $0.025 \%)$ of disinfectants; flume forte, potassium sulfonate and dettol at the rate of $(20 \mathrm{ml} / 200 \mathrm{gm}$ leaves /100 larvae) and offered to infected groups .Larvae fed on treated mulberry leaves along the 1st days of each 4th and 5th larval instars.

\section{1- Biological aspects:}

1.1.Grown larval stage aspects: Grown larval mortality percentage (\%), grown larval duration (days), and cocooning percentage (\%):

Formation of a good cocoon is important aim of rearing silkworm, so the number of formed cocoons of each tray was recorded and percentage of cocooning was calculated as follows:

Cocooning percentage $(\%)=$ Total No of larvae at the beginning of the 5th instar $/$

$$
\text { No. of fresh cocoon } \mathrm{x} 100
$$

1.2. Adult stage aspects: Adult emergence percentages, fecundity of female moths (egg / female) and egg fertility percentages of mulberry silkworms were recorded and tabulated.

\section{Technological aspects:}

2.1. Cocoon indices: Cocoon weight, cocoon shell weight and silk content ratio(\%) was calculated according to Tanaka (1964) formula:

Silk content ratio $(\%)=$

Weight of cocoon shell $\times 100$

\subsection{Reeled silk filament}

indices: Silk filament length (m),Silk filament weight (g) and Silk filament size (dn) which was calculated

The size of reeled silk filaments by denier (dn.) was calculated according to the following equation (Tanaka, 1964):

Size of silk filament (dn.)

Weight of filament $(g) \times 9000$ 
Statistical analysis

Collected data were subjected to statistical analysis of variance test according to Sendecor and Cochran (1967) methods using software COSTAT program.

\section{RESULTS AND DISCUSSION}

\section{Biological aspects:}

\subsection{Grown larval stage:}

\subsubsection{Larval mortality percentage (\%):}

The least percentages of grown larval mortalitywere recorded $(11.50,19.20$ and $26.90 \%)$ for the treatment with $0.1,0.05$ and $0.025 \%$ of potassium sulfonate compound followed by $(28.80,32.70$ and $36.50 \%)$ for the treatment with $0.1,0.05$ and $0.025 \%$ of flume forte compound, while the control (without infection)manifest the highest percentage of grown larval mortality recording $(52.00 \%)$ as shown in Table 1.

\subsubsection{Larval duration of 4th and 5th instars (day):}

Larval treatment with 0.1 and \% flume forte, potassium sulfonate and dettol exhibited the shortest duration (15.50 days), while the control group elongated the grown larval duration(17 days) as shown in Table 1.

\subsubsection{Cocooning percentage:}

The highest percent cocooning of silkworm larvae were recorded (and $96.00,88.00$ and $89.00 \%$ ) for treatment with 0.1 and $0.05 \%$ potassium sulfonate and $0.1 \%$ flume forte, respectively. While, the control group manifested the least cocooning percentage recording $(71.00 \%)$ as shown in Table 1 .

\subsection{Adult Stage:}

\subsubsection{Adult emergence percentage:}

The highest percentages of adult emergence were recorded with larval treatments with 0.1 and $0.05 \%$ concentrations of flume forte, potassium sulfonate and dettol compounds recording 99.60 to $99.90 \%$. While the control group reduced the adult emergence percentages to $63.25 \%$. as shown in Table2.

\subsubsection{Female fecundity (eggs/female):}

It was found that, the infected silkworm fed on the concentrations 0.1 and $0.05 \%$ potassium sulfonate and dettol compounds increased the female fecundity to (437 to 515 eggs/ female), while the control group resulted the least female fecundity recording (281 eggs/ female) as shown in Table 2. 
Table (1): Effect of chemical disinfectants on grown larval mortality percentage, duration and larval duration of mulberry silkworm, Bombyx mori L.

\begin{tabular}{|l|c|c|c|c|}
\hline Compounds & $\begin{array}{c}\text { Conc. } \\
(\mathbf{\%})\end{array}$ & $\begin{array}{c}\text { Grown Larval } \\
\text { mortality(\%) }\end{array}$ & $\begin{array}{c}\text { Grown larval } \\
\text { duration(day) }\end{array}$ & $\begin{array}{c}\text { Cocooning } \\
\text { percentage(\%) }\end{array}$ \\
\hline \multirow{3}{*}{ Flume forte } & -- & 28.8 & 15.50 & 88.00 \\
\cline { 2 - 5 } & $\mathbf{0 . 0 5}$ & 32.7 & 15.50 & 80.00 \\
\cline { 2 - 5 } & $\mathbf{0 . 0 2 5}$ & 36.5 & 15.50 & 81.00 \\
\hline \multirow{3}{*}{$\begin{array}{l}\text { Potassium } \\
\text { Sulphonate }\end{array}$} & $\mathbf{0 . 1}$ & 11.5 & 15.50 & 96.00 \\
\cline { 2 - 5 } & $\mathbf{0 . 0 5}$ & 19.2 & 16.50 & 89.00 \\
\cline { 2 - 5 } & $\mathbf{0 . 0 2 5}$ & 26.9 & 16.50 & 87.00 \\
\hline \multirow{3}{*}{ Dettol } & $\mathbf{0 . 1}$ & 28.8 & 15.50 & 82.00 \\
\cline { 2 - 5 } & $\mathbf{0 . 0 5}$ & 36.5 & 16.50 & 81.00 \\
\cline { 2 - 5 } & $\mathbf{0 . 0 2 5}$ & 40.4 & 16.50 & $\mathbf{9 0 . 0 0}$ \\
\hline Control & & $\mathbf{1 2 . 0 0}$ & $\mathbf{1 7 . 0 0}$ & $\mathbf{2 . 5 2 1 * *}$ \\
\hline L.S.D. conc. & & $\mathbf{1 . 1 7 2 4 9 * *}$ & $\mathbf{0 . 4 8 1 * *}$ & \\
\hline
\end{tabular}

\subsubsection{Egg fertility percentages (\%):}

The highest fertility percentages of eggs laid by female moths were found by the treatments with $0.1 \%$ of flume forte, potassium sulfonate and dettol compounds recording;97.50, 99.30 and $98.50 \%$, respectively. Whereas, the control group recorded the least fertility percentages of eggs laid by female moths $(84.00 \%)$ as shown in Table 2.

The results are in agreement with Kotby et al. (1990) who used papsol and newceresin (powders), formalin and calcium hypochlorite (solutions) as bed-disinfectants on the grown larvae of the silkworm Bombyx mori L. Saha et al.(1995) and Ray and Senapati used cloxacillin (01\%) (2002)). Also, Saad et al. (2012) indicated that the two antibiotics, cefotax and enrotryl at 200, 300 and $400 \mathrm{ppm}$ decreased the larval duration and gave the high percentages of cocooning of Bombyx mori L. Also , in connection, Megalla (1984) clarified that, the presence of ascorbic acid, yeast or chloramphenical alone or in any combination usually increase the percentage of emerged moth.. Majumdar (1982) stated that, silkworm Bombyx mori L. larvae fed on mulberry leaves soaked in water alone or with potassium iodide gave moderate number of deposited eggs laid by females. Ray and Senapati (2002) declared that when 
Table (2): Effect of chemical disinfectants on adult emergence, female fecundity and egg fertility of mulberry silkworm, Bombyx mori L.

\begin{tabular}{|c|c|c|c|c|}
\hline Compounds & $\begin{array}{l}\text { Conc. } \\
(\%)\end{array}$ & $\begin{array}{c}\text { Adult } \\
\text { Emergence }(\%)\end{array}$ & $\begin{array}{l}\text { Fecundity } \\
\text { (egg/female) }\end{array}$ & $\begin{array}{c}\text { Egg fertility } \\
(\%)\end{array}$ \\
\hline \multirow{3}{*}{ Flume forte } & 0.1 & 99.90 & 427 & 97.50 \\
\hline & 0.05 & 99.80 & 419 & 96.80 \\
\hline & 0.025 & 94.70 & 391 & 91.70 \\
\hline \multirow{3}{*}{$\begin{array}{l}\text { Potassium } \\
\text { sulphonate }\end{array}$} & 0.1 & 99.60 & 515 & 99.30 \\
\hline & 0.05 & 99.80 & 442 & 95.30 \\
\hline & 0.025 & 94.80 & 377 & 91.10 \\
\hline \multirow{3}{*}{ Dettol } & 0.1 & 99.90 & 465 & 98.50 \\
\hline & 0.05 & 99.70 & 437 & 94.20 \\
\hline & 0.025 & 90.40 & 400 & 93.50 \\
\hline Control & ---- & 94.30 & 497 & 94.00 \\
\hline L.S.D. Conc. & & $2.111 * *$ & $61.73 * *$ & $5.494 * *$ \\
\hline
\end{tabular}

fed the $5^{\text {th }}$ instar larvae, leaves containing higher nutrient level at $0.1 \%$ Gentamycin (antibiotic) the fecundity percentage of silkworm was increased.

\section{Technological studies:}

\subsection{Cocoon indices:}

\subsubsection{Fresh cocoon weight (g):}

The highest values of fresh cocoon weights were recorded (1. 458, 1. 436 and $1.440 \mathrm{~g}$ ) for $0.1 \%$ flume forte, potassium sulfonate compounds and dettol, respectively as shown in Table 3.

\subsubsection{Cocoon shell weight:}

Flume forte compound and dettol $(0.1 \%)$ manifested the highest values of cocoon shell weight recording ( 0.328 and $0.330 \mathrm{~g}$ ) compared with $(0.262 \mathrm{~g})$ for control group as shown in Table 3.

\subsubsection{Silk content ratio:}

No significant effect of the three tested compounds appeared as shown in Table 3.

\section{2: Reeled filament parameters:}

\subsubsection{Silk filament length $(m)$ :}

The treatments $0.1,0.05 \%$ of flume forte, potassium sulfonate and dettol caused the highest means of silk filament length recording; 
Table (3): Effect of chemical disinfectants on cocoon weight, cocoon shell weight and silk content ratio of mulberry silkworm, Bombyx mori L

\begin{tabular}{|l|c|c|c|c|}
\hline \multirow{3}{*}{ Compounds } & $\begin{array}{c}\text { Conc. } \\
(\mathbf{\%})\end{array}$ & $\begin{array}{c}\text { Cocoon weight } \\
(\mathbf{g})\end{array}$ & $\begin{array}{c}\text { Cocoon shell } \\
\text { weight }(\mathbf{g})\end{array}$ & $\begin{array}{c}\text { Silk content ratio } \\
(\mathbf{\%})\end{array}$ \\
\hline \multirow{3}{*}{ Flume forte } & $\mathbf{0 . 1}$ & 1.458 & 0.328 & 22.47 \\
\cline { 2 - 5 } & $\mathbf{0 . 0 5}$ & 1.392 & 0.312 & 22.41 \\
\cline { 2 - 5 } Potassium & $\mathbf{0 . 0 2 5}$ & 1.206 & 0.306 & 25.37 \\
\cline { 2 - 5 } & $\mathbf{0 . 1}$ & 1.436 & 0.306 & 21.31 \\
\hline \multirow{3}{*}{ sulphonate } & $\mathbf{0 . 0 5}$ & 1.122 & 0.280 & 24.96 \\
\cline { 2 - 5 } & $\mathbf{0 . 0 2 5}$ & 1.078 & 0.270 & 25.05 \\
\hline \multirow{3}{*}{ Dettol } & $\mathbf{0 . 1}$ & 1.460 & 0.330 & 22.63 \\
\cline { 2 - 5 } & $\mathbf{0 . 0 5}$ & 1.192 & 0.280 & 21.45 \\
\cline { 2 - 5 } & $\mathbf{0 . 0 2 5}$ & 1.128 & 0.242 & $\mathbf{2 0 . 4 4}$ \\
\hline Control & $-\cdots-----$ & $\mathbf{1 . 2 8 2}$ & $\mathbf{0 . 2 6 2}$ & $\mathbf{n s}$ \\
\hline L.S.D. & & $\mathbf{0 . 1 2 8} * *$ & $\mathbf{0 . 0 5 5} * *$ & \\
\hline
\end{tabular}

(1212.90,1118.50 and $1013 \mathrm{~m}$, respectively. The lowest mean of silk filament lengths was recorded with control group $(952.45 \mathrm{~m})$ as shown in Table 4.

\subsubsection{Silk filament weight (g):}

Obtained results cleared that, $0.1 \%$ flume forte compound and potassium sulfonate exhibited the highest value of silk filament weight recording (0.300 and $280 \mathrm{~g})$,respectively. The control recorded $(0.233 \mathrm{~g})$ as shown in Table 4.

\subsubsection{Silk filament size (dn):}

When treated the infected silkworm with $0.1 \%$ flume forte compound and $0.1 \%$ potassium sulfonate the highest silk filaments sizes recorded (2.229, and $2.292 \mathrm{dn}$., respectively compared to $2.202 \mathrm{dn}$. for control as shown in Table 4.

Majumdar (1982) mentioned that feeding silkworm, Bombyx mori L.larvae on mulberry leaves soaked in water alone or with potassium iodide 25, 50 or $100 \mathrm{mu} \mathrm{g} / \mathrm{m}$. increased the weight of silk.. Saad et al. (2012) indicated that the two antibiotics (Cefotax and Enrotryl) at concentrations of 
Table (4): Effect of chemical disinfectants on filament length, filament weight and filament Size of mulberry silkworm, Bombyx mori L.

\begin{tabular}{|c|c|c|c|c|}
\hline Compounds & $\begin{array}{c}\text { Conc. } \\
(\%)\end{array}$ & $\begin{array}{c}\text { Filament } \\
\text { length } \\
(\mathrm{m} .)\end{array}$ & $\begin{array}{l}\text { Filament } \\
\text { weight } \\
\text { (g) }\end{array}$ & $\begin{array}{c}\text { Filament } \\
\text { Size } \\
(\text { dn. })\end{array}$ \\
\hline \multirow{3}{*}{ Flume forte } & 0.1 & 1212.90 & 0.300 & 2.229 \\
\hline & 0.05 & 1035.70 & 0.255 & 2.219 \\
\hline & 0.025 & 965.90 & 0.198 & 1.857 \\
\hline \multirow{3}{*}{$\begin{array}{l}\text { Potassium } \\
\text { sulphonate }\end{array}$} & 0.1 & 1118.50 & 0.280 & 2.292 \\
\hline & 0.05 & 990.70 & 0.250 & 2.276 \\
\hline & 0.025 & 962.30 & 0.200 & 1.903 \\
\hline \multirow{3}{*}{ Dettol } & 0.1 & 1013.90 & 0.235 & 2.109 \\
\hline & 0.05 & 975.60 & 0.207 & 2.061 \\
\hline & 0.025 & 922.80 & 0.195 & 1.684 \\
\hline Control & --- & 952.45 & 0.233 & 2.202 \\
\hline L.S.D. conc. & & $161.48 * *$ & $0.0385 * *$ & $0.419 * *$ \\
\hline
\end{tabular}

(400 ppm) caused significant increase of filament weight, length and size. Sailaja et al. (1991) reported that oral treatment with the antibiotic oxy tetracycline increased the cocoon weight of Bombyx mori L. west value of cocoon weights recording $(0.830 \mathrm{~g})$.

\section{REFERENCES}

Aneja, K. R. (2003): Experiments In Microbiology, Plant Pathology And Biotechnology. New Age International (P) Limited Publeshers, 4th Edition:376 pp..

Bali, R. K.; Koul, A. and Ram, K. (2008): Evaluation of some low cost materials as silkworm bed disinfectants. Journal of Research, SKUAST- J., 7(1): 118- 121.

Dechu, P. S.; Govindan, R.; Devaiah, M. C. and Narayanaswamy, T.K. (1997): Effect of antibiotics on growth and cocoon parameters of silkworm, Bombyx mori L. Mysore J. Agric. Sci., 31: 41-46.

EL-Zohairy, M.; M. egahed; F. Kotby; A. Hosny and A. Zannoon (1990).Protection of young and grown larvae of Bombyx mori L. against diseases by ded-disinfectants. Egypt. J. App. Sci., 5 (7):32

Govindan, R.; Magadum, S.B.; Magadum, V.B.; Devaiah, M. C. and Narayanaswamy, T.K. (1990) Effect of fortification of streptomycin 
and procaine penicillim on economic traits of eri silkworm. Current Research, Univers. Agric. Sci., Bangalore., 19 (11): 196-197.

Kotby, F.; Megahed, F.; El-Zohairy, M.; Hosny, A. and Zannoon, A.A. (1990): Effect of significant dosages of bed-disinfectants applied at different intervals to the grown larvae of the silkworm Bombyx mori $\mathrm{L}$. Egypt J. App. Sci; 5(8):245-33.

Krishnaswami, S.(1978): New technology of silkworm rearing. Central Sericulture Research and Training Inst. Mysore Bull., 2:1-10.

Majumdar, A. C. (1982): Note on the physiology effects on the growth and reproduction of silkworm fed on mulberry leaves socked in potassium iodide. Indian J. Agric. Sci., 52(4): 250-252.

Megalla, A. H. (1984): Effect of certain dietary constituents on silkworms. $\mathrm{Ph}$. D. Thesis, Plant Protection department, Faculty of Agriculture Ain-Shams University: $126 \mathrm{pp}$.

Ray, N. and Senapati, S. K. (2002): Studies on combined effect of fertilizer levels and antibiotic on rearing performance of bivoltine silkworm, Bombyx mori L. under terai region of West Bengal. Crop Res., 23(1):150-155.

Radha, N. V.; Natarajan, T.; Muthukrishnan, T. S. and Oblisami, S. (1981): Effect of antibiotics on the growth and productivity of mulberry silkworms. Proceedings of Sericulture Symposium and Seminar. TNAU, Coimbatore : 173 - 177.

Saad, M. I. S.; Hassan, Eman, M. and Zannoon , A. A. (2012): Effect of some antibiotics on the biology and silk production of mulberry silkworm, Bombyx mori L. Egypt. J. Agric. Res., 90 (2): 537-545.

Saha, A. K.; Rahaman, M. S.; Saha, B. N. and Das, D. K. (1995): Effect of antibiotics on the growth and rearing performance of silkworm, Bombyx mori". J. Asiatic Soc. Bangladesh Sci., 21 (2): 289-292.

Sailaja, D.; Devamma, M.N.; Naidu, B.P. and Sreeramulu, A. (1991): Treatment of terramycin on the development and organic composition of silkworm Bombyx mori. Environ. \& Ecol., 9(3):656 - 658.

Sanakal, R.D.; Ingalhalli, S.S. ; Sinph, K.K. ; Basavarajappa,S. ; Hinchigeri, S.B. and Savanurmath, C.J. (1996): Infectious Flacherie of the silkworm Bombyx mori in northern Districts of Karnataka, India. Indian J. Seric., 35 (2):90 - 94.

Sendecor, G. W. and Cochran, W. G. (1967): Statistical Methods". Iowa State Univ. Press, Amer. Iowa.

Serbanescu, S. and Pau, E. (1989):Prevention and control methods for viral and bacterial diseases in silkworms. Lucrarile Institutului de Cercetari Veterinare si Biopreparate "Pasteur", 18:147 - 154. 
Tanaka, Y. (1964): Manual of Sericology. Central Silk Board, Bombay, (95)-B, Megdoot, Marine Drive, 216-220.

Zannoon, A. A. and Omara, Sh. M. (1994): Efficiency of certain natural materials as mountages for mulberry silkworm, Bombyx mori L. Egypt. J. Appl. Sci., 9 (8): 691-696.

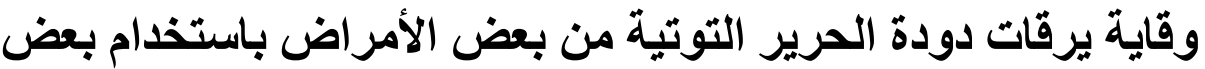

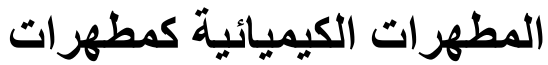

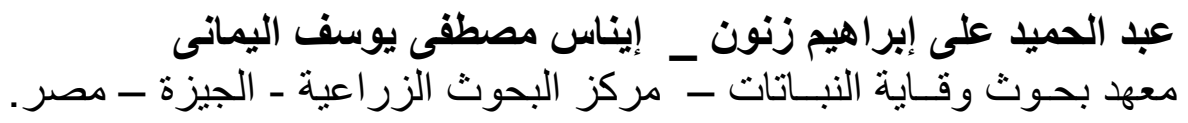

أجريت هذه الدر اسة لتقييم استخدام المركبات فلوم فورت و بوت باسيوم سلفونيت و

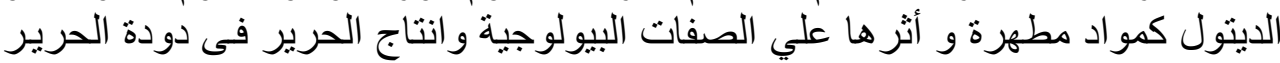

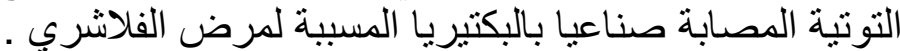

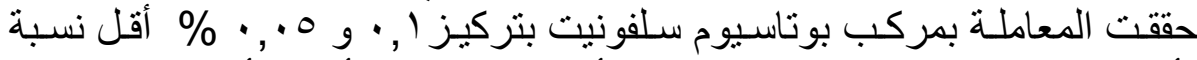

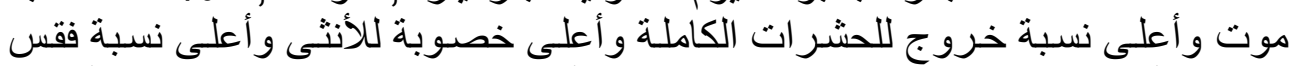

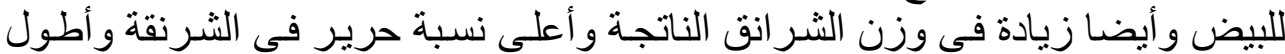

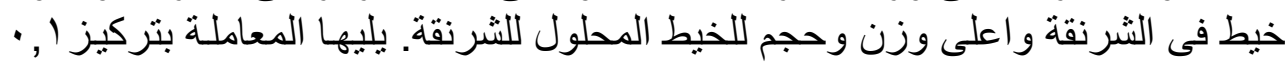

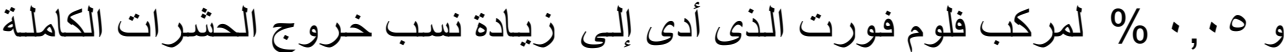

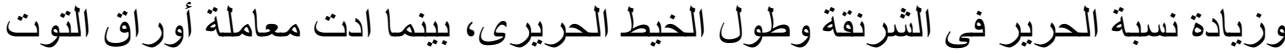

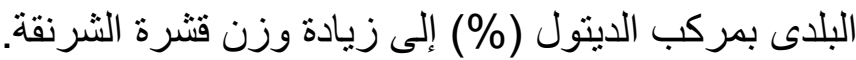

